\title{
Christianity, Family, Students, and COVID-19
}

\author{
Lindsay B. Carey ${ }^{1}$ - Jeffery Cohen ${ }^{2} \cdot$ Harold G. Koenig ${ }^{3,4} \cdot$ Terrence Hill $^{5}$. \\ Ezra Gabbay $^{6} \cdot$ Carl Aiken $^{7,8}$. Jacinda R. Carey ${ }^{1}$
}

Published online: 12 October 2021

(C) The Author(s), under exclusive licence to Springer Science+Business Media, LLC, part of Springer Nature 2021

\begin{abstract}
Four substantial topics are explored in this issue of the Journal of Religion and Health, namely: (1) Christianity, (2) family and faith dynamics, (3) the spiritual and religious experiences of students from Islamic, Christian, Buddhist, Hindu, and Jewish perspectives, and lastly, (4) the lingering effects of COVID-19. This issue also notes the diamond jubilee-60th year-of JORH (2021).
\end{abstract}

Keywords Christianity $\cdot$ Family $\cdot$ Students $\cdot$ COVID-19 $\cdot$ Religion $\cdot$ Spirituality

\section{Introduction}

The Journal of Religion and Health (JORH) commenced in 1961 as a journal of the Academy of Religion and Mental Health, which was an academic wing of the US Blanton-Peale Institute (founded in 1937). As noted by Levin (2020, p. 4-5) in his textbook 'Religion and Medicine,' the publication of JORH was one of the notable outcomes of the 'religion and health movement' during the first half of the twentieth Century. The first Editor, Rev. Dr. George Christian Anderson (1907-1976: who was an active cleric in mental health), commenced JORH with only one issue published in 1961 and with only seven articles, but with the clear purpose to correlate "medicine, the behavioral sciences, theology, and philosophy-disciplines devoted to healing and to improving our total health" (Anderson, 1961, p. 9). Some noteworthy authors published articles in the initial years of JORH, such as Viktor E. Frankl (1905-1997), Seward Hiltner (1909-1984), and Wayne E. Oates (1917-1999). Today, published by Springer Nature, JORH currently has six issues per year and publishes approximately 50 articles each issue, totaling around 300 published articles per annum (not including online first articles-usually over 100). Given the substantial volume of articles that are received every year (up to a 1,000 per annum),

Lindsay B. Carey

Lindsay.Carey@latrobe.edu.au

Extended author information available on the last page of the article 
$J O R H$ has successfully progressed from a collection of randomly published articles to publishing thematically and thus turning each JORH issue into a useful anthology with designated topic areas that are of interest to both readers and researchers. Looking into the future, we can only wish JORH well and hope that the following generations will respect the privilege of preserving and promoting $J O R H$, as well as contributing to its legacy.

As we move forward into the holiday season (after another challenging year of COVID), this last issue for 2021 of JORH (2021), commences with articles that reflect upon aspects relating to Christianity. Christianity (along with Islam) was a key theme in a previous issue of JORH (2021a). Currently, Christianity has the largest percentage of religious believers across the world constituting $31.2 \%$ of religious adherents and projected to remain so until at least 2060 (Carey, et al., 2021a; PRC, 2017). Perhaps understandably, and as reflected within this issue of $J O R H$, there are many religious and healthcare dynamics that Christianity touches. Various articles within this issue of JORH consider the Catholic denomination and its priests, as well as the Catholic healthcare system, prayer, pilgrimages, and biblical relevance to health care, along with a description of various non-denominational Christian healthcare rehabilitation programs.

Concerns relating to families are also considered in this particular issue of JORH with respect to women, children, and adolescents. However, articles relating to students (primary, secondary, and tertiary) dominate this issue of JORH from Islamic, Christian, Buddhist, Hindu, and Jewish perspectives. Lastly, as vaccination rates increase, articles relating to COVID-19 are diminishing and this issue only presents two articles on this topic — a vast reduction compared to previous JORH issues.

\section{Christianity}

Within this section, the first collection of articles examines aspects of the Catholic church, namely (i) bibliometric analysis and visualization of Catholic healthcare research from 1973 to 2019, (ii) the Lourdes pilgrimage and quality of life, (iii) transcendent experiences among pilgrims to Lourdes, (iv) occupational stress among Catholic priests, (v) intercessory rote prayer, life longevity of Roman Catholic bishops, and (vi) the experiences and perceived effects of praying the Rosary. This section concludes with (vii) an historical review of Theophrastus Bombastus Von Hohenheim (1493-1541), a German-Swiss Catholic lay-theological reformer, philosopher, and alchemist-physician who sought to improve both medical and ecclesiastical practices.

Subsequently, a range of topics are presented which consider more contemporary healthcare research such as (viii) a process evaluation of a faith-based multicomponent behavioral intervention to reduce stroke risk in Mexican Americans-the SHARE Project, (ix) faith communities' improvements in readiness to engage in addiction resilience and recovery programs, (x) religion and recovery among individuals experiencing homelessness, (xi) Korean Christian young adults' religiosity and post-traumatic growth, (xii) the benefits of spiritual diaries in Korea, (xiii) the psychology, pursuit, sense of power and structural patterns of biblical social 
relations, (xiv) what the Gospel story of the hemorrhaging woman can teach nurses (and us all), (xv) the experience of gender incongruity in the Christian Church, (xvi) sexual practice and decision making among Christian women in South Africa, (xvii) Christian Churches and the prevention of preadolescent aggression and violence in Puerto Rico, (xviii) cognitive and behavioral changes arising from spirituality, and finally, (xix) the interaction between death concerns and religiosity through an evaluation of a human Jesus.

\section{Family}

This section considers a wide range of family topics covering (1) broad familial issues, (2) factors affecting children and adolescents, and finally, (3) concerns affecting the health of women-a recurrent topic previously discussed in JORH (Carey et al, 2021b). Firstly, research related to familial issues: (i) family planning attitudes, religious orientation, and fatalistic tendency levels in Turkey, (ii) the relationship between workplace spirituality and work-to-family enrichment in Malaysia, and (iii) an exploratory study of low-income family experiences of early childhood inclusive education in New Zealand.

Secondly, there are articles on children and adolescents: (iv) religious and spiritual practices used by children and adolescents to cope with cancer, (v) religious support moderating the long reach of adverse childhood events upon physical health, and (vi) recollections of childhood sexual abuse in Afghanistan.

Thirdly, women's health is addressed: (vii) women's and their partners' adjustment to the threat of breast cancer, (viii) effects of sexual behavior, intercourse, satisfaction-related myths, and perceived spirituality on sexual dysfunctions in Muslim pregnant women, (ix) the relation between religious coping, adjustment to fertility, being affected by infertility, and satisfaction with life among Turkish women with infertility, and lastly, (x) the power of women's faith in coping with intimate partner violence.

\section{Students}

Another area of increasing research concerns student issues. This section begins with (i) a scientific mapping of the literature regarding the spirituality and wellbeing of children, adolescent, and adult students. Subsequently, students from different religious persuasions are researched, namely those from Islamic, Christian, Jewish, and Hindu backgrounds.

Firstly, Islamic articles are considered: (ii) nursing students' perception levels of spirituality and spiritual care in Turkey, (iii) the relationship between international students' health perceptions and healthy lifestyle behaviors, (iv) the association between religious attitudes and aggression levels in Turkish university students, (v) the use of Islamic patterned art therapy and the healing of psychological problems among university students, (vi) determining the knowledge and attitudes of theological students in Turkey toward brain death and organ donation, (vii) the relationship 
between Turkish nursing students' perceptions of spiritual care and their attitudes toward death, and (viii) what intern nursing students in Turkey think about death and end-of-life care.

Secondly, coming from a Christian perspective, this section explores (ix) servant leadership and spirituality among undergraduate and graduate nursing students, (x) religious problem-solving styles and life satisfaction among students, (xi) religiosity's association with motivation to start and stop smoking among adolescent students in Brazil, (xii) listening to transgender and gender diverse students on Christian college campuses, and (xiii) a novel experiential course for undergraduate medical education on religion and spirituality.

Thirdly, the remaining articles consider students of the Jewish faith, Buddhism, and Hinduism: (xiv) US synagogues and the promotion of youth physical activity programs, (xv) religion, strain, and suicidality among Chinese young adult students, and lastly, (xvi) the impact of a course on the Bhagavad Gita for college students.

\section{COVID-19}

Finally, there are the two articles related to COVID-19. This pandemic, which has caused significant physical, psychological, social, economic, religious, and spiritual impact, has now been addressed across seven $\mathrm{JORH}$ issues. According to WHO (2021), the total number of COVID-19 cases worldwide now exceeds 230 million and has caused nearly 5 million deaths-with the USA, India, and Brazil having the largest number of cases and deaths (Table 1).

It should not be surprising that by October 2021, Elsevier SCOPUS reported a record number of COVID-19 publications with just over 200,000 peer-reviewed articles having been published (Table 2). As we finalize this issue, JORH will have published (in total) 80 articles on COVID-19. Within this issue, two

Table 1 Top 20 nations with the highest COVID-19 cases and deaths (October 1, 2021)

\begin{tabular}{lllllr}
\hline Country & Cases & Deaths & Country & Cases & Deaths \\
\hline USA & $42,966,938$ & 689,099 & Colombia & $4,955,848$ & 126,261 \\
India & $33,766,707$ & 448,339 & Italy & $4,627,355$ & 130,921 \\
Brazil & $21,399,584$ & 596,122 & Germany & $4,237,619$ & 93,711 \\
UK & $7,807,040$ & 136,662 & Indonesia & $4,216,728$ & 142,026 \\
Russia & $7,535,548$ & 208,142 & Mexico & $3,655,395$ & 276,973 \\
Turkey & $7,154,070$ & 64,054 & Poland & $2,908,432$ & 75,666 \\
France & $8,799,222$ & 114,475 & South Africa & $2,902,672$ & 87,626 \\
Iran & $5,567,040$ & 120,428 & Philippines & $2,549,966$ & 38,294 \\
Argentina & $5,255,261$ & 115,130 & Ukraine & $2,435,413$ & 56,446 \\
Spain & $4,959,091$ & 86,415 & Malaysia & $2,245,695$ & 26,335 \\
\hline
\end{tabular}

Source: WHO (2021). WHO-COVID-19 Statistics Dashboard; see also Carey et al., 2021b for comparable statistics April 2021 
Table 2 'COVID-19': Refereed Journal Articles Published 2019-2021 (October) *

\begin{tabular}{lll}
\hline Year & Articles published & Cumulative \\
\hline 2019 & 54 & 54 \\
2020 & 84,731 & 84,785 \\
2021 & 119,478 & $204,263^{* *}$ \\
\hline
\end{tabular}

Note: *Source: SCOPUS/Elsevier (2021): Title, Abstract, Keyword: 'COVID'; Total October 2021

${ }^{* * *}$ Figures do not include non-peer-reviewed publications

additional articles examine (i) anxiety during the COVID-19 pandemic among academics in the Muslim World and (ii) the collaboration between Christian faith-based communities and public health programs during the pandemic.

\section{Call for Papers}

As stated in the previous editorial (Carey et al., 2021c), this year marks two decades since the devastating event of September 11, 2001. Authors are encouraged to submit their reflections upon 9/11 for future issues of the journal. Please feel free to contact one of the editors if you wish to discuss a potential paper. Submissions are made through the Editorial Manager on the JORH Web site: https://www.springer. com/journal/10943/submission-guidelines.

\section{References:}

Anderson, G. C. (1961). Editorial. Journal of Religion and Health, 1(1) 9-11. https://doi.org/10.1007/ BF01532008

Carey, L. B., Cohen, J., Koenig, H. G., Gabbay, E., \& Carey, J. R. (2021a). COVID-19, Islam and Christianity. Journal of Religion and Health, 60(2), 621-624. https://doi.org/10.1007/s10943-021-01228-3

Carey, L. B., Cohen, J., Koenig, H. G., Gabbay, E., \& Carey, J. R. (2021b). COVID-19, Sex, Addictions, Women's Health, Care of the Elderly, and Medical Education. Journal of Religion and Health, 60(3), 1425-1429. https://doi.org/10.1007/s10943-021-01264-z

Carey, L. B., Cohen, J., Koenig, H. G., Hill, T., Gabbay, E., Aiken, C., \& Carey, J. R. (2021c). Remembering 9/11, Moral Injury, COVID-19 and Measuring Religion, Spirituality and Health. Journal of Religion and Health, 60(5), 2977-2982. https://doi.org/10.1007/s10943-021-01423-2

JORH. (2021). Journal of Religion and Health, 60(6). Springer Nature. https://link.springer.com/journal/ 10943/volumes-and-issues/60-6

Levin, J. (2020). Religion and Medicine: A History of the Encounter Between Humanity's Two Greatest Institutions. Oxford University Press. https://doi.org/10.1093/oso/9780190867355.001.0001

PRC (2017). 'The Changing Global Religions Landscape'. Pew Research Centre: https://www.pewforum. org/2017/04/05/the-changing-global-religious-landscape/

SCOPUS (2021). SCOPUS Data Base. Netherlands: Elsevier https://www.elsevier.com/solutions/scopus WHO (2021). WHO-COVID-19-Statistics. Geneva: World Health Organization. https://covid19. who.int/

Publisher's Note Springer Nature remains neutral with regard to jurisdictional claims in published maps and institutional affiliations. 


\section{Authors and Affiliations}

\section{Lindsay B. Carey ${ }^{1}$ - Jeffery Cohen ${ }^{2} \cdot$ Harold G. Koenig ${ }^{3,4} \cdot$ Terrence Hill $^{5}$. Ezra Gabbay $^{6} \cdot$ Carl Aiken $^{7,8} \cdot$ Jacinda R. Carey ${ }^{1}$}

Jeffery Cohen

jeffrey.cohen@nd.edu.au

Harold G. Koenig

Harold.Koenig@duke.edu

Terrence Hill

terrence.hill@utsa.edu

Ezra Gabbay

ezg9002@med.cornell.edu

Carl Aiken

caiken@drew.edu

Jacinda R. Carey

Jacinda.Carey@gmail.com

1 Public Health Palliative Care Unit, La Trobe University, Melbourne, Australia

2 School of Medicine (Sydney), University of Notre Dame Australia, St Vincent's Private Hospital Sydney, New South Wales, Australia

3 Department of Psychiatry and Behavioral Sciences, and Department of Medicine, Duke University Health Systems, Durham, NC, USA

4 Division of Psychiatry, Department of Medicine, King Abdulaziz University, Jeddah, Saudi Arabia

5 The University of Texas at San Antonio, San Antonio, TX, USA

6 Division of General Internal Medicine, Department of Medicine, Hospital Medicine Section, Weill Cornell Medicine, New York, NY, USA

7 Drew University Alumni, Madison, NJ, USA

8 Women's and Children's Hospital, Adelaide, South Australia, Australia 